\title{
Recovering Iron from Iron Ore Tailings and Preparing Concrete Composite Admixtures
}

\author{
Chang Tang ${ }^{1,2,3}$, Keqing $\mathrm{Li}^{1,2, *}$, Wen $\mathrm{Ni}^{1,2, *}$ and Duncheng Fan ${ }^{1,2}$ \\ 1 Key Laboratory of the Ministry of Education of China for High-Efficient Mining and Safety of Metal Mines, \\ University of Science and Technology Beijing, Beijing 100083, China; b20160058@xs.ustb.edu.cn (C.T.); \\ b20170035@xs.ustb.edu.cn (D.F.) \\ 2 School of Civil and Resource Engineering, University of Science and Technology Beijing, \\ Beijing 100083, China \\ 3 Hebei Technology Research Center for Application of High Performance Concrete with Ultra-low \\ Environment Load, Shahe 054100, China \\ * Correspondence: lkqing2003@163.com (K.L.); niwen@ces.ustb.edu.cn (W.N.)
}

Received: 15 March 2019; Accepted: 9 April 2019; Published: 15 April 2019

\begin{abstract}
Iron ore tailings (IOTs) are a form of solid waste produced during the beneficiation process of iron ore concentrate. In this paper, iron recovery from IOTs was studied at different points during a process involving pre-concentration followed by direct reduction and magnetic separation. Then, slag-tailing concrete composite admixtures were prepared from high-silica residues. Based on the analyses of the chemical composition and crystalline phases, a pre-concentration test was developed, and a pre-concentrated concentrate (PC) with an iron grade of $36.58 \mathrm{wt} \%$ and a total iron recovery of $83.86 \mathrm{wt} \%$ was obtained from a feed iron grade of $12.61 \mathrm{wt} \%$. Furthermore, the influences of various parameters on iron recovery from PC through direct reduction and magnetic separation were investigated. The optimal parameters were found to be as follows: A roasting temperature of $1250{ }^{\circ} \mathrm{C}$, a roasting time of $50 \mathrm{~min}$, and a 17.5:7.5:12.5:100 ratio of bitumite/sodium carbonate/lime/PC. Under these conditions, the iron grade of the reduced iron powder was $92.30 \mathrm{wt} \%$, and the iron recovery rate was $93.96 \mathrm{wt} \%$. With respect to the original IOTs, the iron recovery was $78.79 \mathrm{wt} \%$. Then, highly active slag-tailing concrete composite admixtures were prepared using the high-silica residues and $\mathrm{S} 75$ blast furnace slag powder. When the amount of high-silica residues replacing slag was $20 \%$, the strength of cement mortar blocks at 7 days and 28 days was $33.11 \mathrm{MPa}$ and $50 \mathrm{MPa}$, respectively, whereas the activity indices were 89 and 108, respectively. Meanwhile, the fluidity rate was appropriately 109 . When the content of high-silica residues replacing slag was not more than $30 \%$, the quality of mineral admixtures was not reduced. Last but not least, reusing the high-silica residues during iron recovery enabled the complete utilization of the IOTs.
\end{abstract}

Keywords: iron ore tailings; iron recovery; concrete composite admixtures; reuse

\section{Introduction}

Iron ore tailings (IOTs) are a form of solid waste produced during the beneficiation process of iron ore concentrate. Among all kinds of mining solid waste, IOTs are one of the most common solid wastes in the world due to their high output and low utilization ratio. In China, the generation of IOTs has increased rapidly due to recent growth in the iron and steel industries. According to some recent statistics, the output of iron tailings was around 500 million tons in 2015 [1]. Although there has already been a recent trend of gradual reduction in the amount of IOTs produced, the total accumulation of IOTs has exceeded 7.5 billion tons in China [2,3]. The enormous amount of IOTs deposited as waste incurs a high economic cost for waste management and also creates serious environmental 
problems and security risks. However, some studies have found that waste IOTs have an iron grade of approximately $8 \mathrm{wt} \%-12 \mathrm{wt} \%$ on average, and occasionally as high as $27 \mathrm{wt} \%$ [4,5]. If these materials contain $10 \mathrm{wt} \%$ iron on average, 750 million tons of metallic iron is lost during the disposal of IOTs.

With the passage of time, the earth's iron ore resources continue to decline. Due to this reason, IOTs might become valuable resources in the future. Currently, the processes for utilizing IOTs can be mainly divided into two categories, namely iron recovery from IOTs and the use of IOTs as raw materials. Recovery is a well-known process, and many recovery methods have been developed, including gravimetric separation, magnetic separation, and flotation separation [5-8]. However, these processes create new waste streams after the recovery of iron and are inefficient when using traditional mineral processing techniques. IOTs can also be used to make other products, such as ceramic tiles [9,10], engineered cementitious composites [11], IOT-filled polypropylene cement, and epoxy composites [12,13], and underground backfill mining materials [3]. The conversion of solid industrial waste into other valuable products has received considerable attention in recent years. However, in these processes, iron within the utilized IOTs is not recovered, thus wasting large amounts of iron resources.

Recently, a method involving direct reduction followed by magnetic separation has been used to recover iron from red mud, vanadium tailings, pyrite slag, copper slag, cyanide tailings, and IOTs [14-19]. This method has the advantage of high iron recovery, and is especially suitable for ore with a low iron grade. However, there is no suitable method for dealing with the secondary tailings after iron selection.

In this study, Qidashan IOTs were comprehensively utilized to generate zero-emission IOT waste. The IOTs were owned by the Anshan Iron Steel Group (AISG) in northeastern China and were discharged after the processing of iron minerals from Anshan magnetite quartzite, because iron recovery or reuse of these IOTs as raw materials for value-added products was not economically viable. Meanwhile, due to the low iron content of IOTs, the cost of recovering iron through direct reduction-magnetic separation is high. Consequently, an innovative technique called "pre-concentration followed by direct reduction and magnetic separation technology" was developed [20]. According to this method, pre-concentration is initially undertaken to obtain a pre-concentrated concentrate (PC) and high-silicon residue. The PC is used as a raw material for direct reduction after pre-concentration, and the resulting high-silicon residue from this process is used to prepare slag-tailing concrete composite admixtures that consist of high-silicon residues and blast furnace slag (BFS) discharged by the Ansteel Group Corporation during iron smelting. The reduced iron powder can be conveniently used for electric arc furnace steelmaking by the nearby Ansteel Group Corporation facility as a high-grade alternative raw material to steel scrap. The admixtures can be used to partially or fully replace cement to produce various construction concretes or filling materials for backfilling the mined-out area. Therefore, this technology can truly achieve full iron recovery from IOTs and approaches zero-tailing mining, thus resulting in substantial economic and social benefits. Notably, the amount of silicate residues remaining after direct reduction followed by magnetic separation can reach up to $20 \mathrm{wt} \%$ of the total IOTs, and therefore they are used as cement raw meal. In this paper, iron was recovered from IOTs using pre-concentration followed by direct reduction and magnetic separation, whereas slag-tailing concrete composite admixtures were subsequently prepared using the high-silicon residues separated from IOTs.

\section{Materials and Methods}

\subsection{Raw Materials}

\subsubsection{Iron Ore Tailings}

IOTs were sampled from a storage dam at the Qidashan iron ore dressing plant in Anshan, which is in the Liaoning province of China. The chemical composition of this material is presented in Table 1 : The total iron content was approximately $12.61 \mathrm{wt} \%$. The crystalline phases in the received IOTs are shown in Figure 1, and included quartz, hematite, and magnetite. After analyzing the iron phases, approximately $58.92 \mathrm{wt} \%$ of the total iron was in the form of magnetite or hematite (Table 2), whereas 
$37.31 \mathrm{wt} \%$ of the total iron was in the form of silicate minerals, such as chlorite and hornblende. It is worth noticing that the latter materials cannot be separated effectively using traditional magnetic separation methods.

Table 1. Chemical composition of the iron ore tailings (IOTs).

\begin{tabular}{cccccccccccc}
\hline Components & $\mathrm{TFe}$ & $\mathrm{SiO}_{2}$ & $\mathrm{CaO}$ & $\mathbf{M g O}$ & $\mathrm{Al}_{2} \mathrm{O}_{3}$ & $\mathrm{Na}_{2} \mathrm{O}$ & $\mathrm{K}_{2} \mathrm{O}$ & $\mathbf{M n O}$ & $\mathrm{TiO}_{2}$ & $\mathbf{S}$ & $\mathbf{P}$ \\
\hline Content/wt $\%$ & 12.61 & 75.46 & 1.70 & 1.75 & 1.65 & 0.32 & 0.34 & 0.13 & 0.06 & 0.10 & 0.03 \\
\hline
\end{tabular}

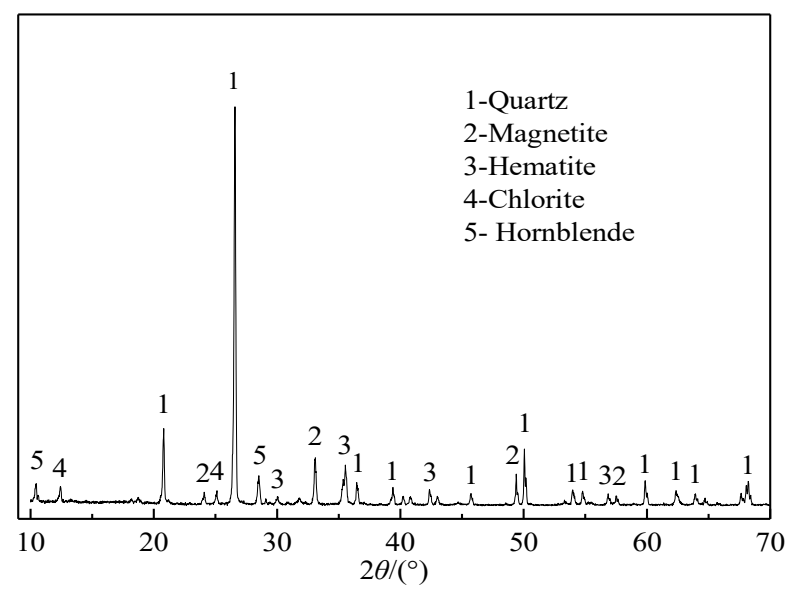

Figure 1. XRD pattern of the IOTs.

Table 2. Analysis of the iron phases in the IOTs.

\begin{tabular}{ccccccc}
\hline Phases & Magnetic Iron & Hematite and Limonite & Iron Carbonate & Iron Silicate & Iron Sulfide & TFe \\
\hline Iron content $/ \mathrm{wt} \%$ & 2.29 & 5.16 & 0.39 & 4.72 & 0.08 & 12.64 \\
Fraction $/ \mathrm{wt} \%$ & 18.12 & 40.82 & 3.09 & 37.34 & 0.63 & 100.00 \\
\hline
\end{tabular}

\subsubsection{Reducing Coal}

The reducing coal used in this study was bitumite. Its composition is listed in Table 3. Carbon $(45.16 \mathrm{wt} \%)$ was the major active reagent during the direct reduction process.

Table 3. General analysis of the bitumite.

\begin{tabular}{ccccc}
\hline Ingredients & Moisture & Ash & Volatiles & Fixed Carbon \\
\hline Content $/ \%$ & 9.88 & 16.20 & 28.76 & 45.16 \\
\hline
\end{tabular}

\subsubsection{Additives}

Analytical-grade lime $(\mathrm{CaO})$ and sodium carbonate $\left(\mathrm{Na}_{2} \mathrm{CO}_{3}\right)$ were used as additives in this study.

\subsubsection{S75, Portland Cement PI42.5, and Standard Sand}

S75 ground-granulated blast furnace slag powder was produced by the Anshan Iron Steel Group in northeastern China, and the specific surface area was $353 \mathrm{~m}^{2} / \mathrm{kg}$. The cement used was Portland cement with a strength grade of 42.5 (complying with the Chinese National Standard GB 175-1999) and was produced by the Tangshan Jidong Cement Co., Ltd., in China. Standard sand was manufactured and packed by the Xiamen ISO Standard Sand Co., Ltd., in China.

\subsection{Experimental Methods}

The experimental workflow is shown in Figure 2. The workflow includes pre-concentration, direct reduction-magnetic separation, and final products. Among them, iron concentrate I and 
iron concentrate II represent the magnetic products after two magnetic separations $(0.11 \mathrm{~T}$ and $0.8 \mathrm{~T}$ ), respectively.

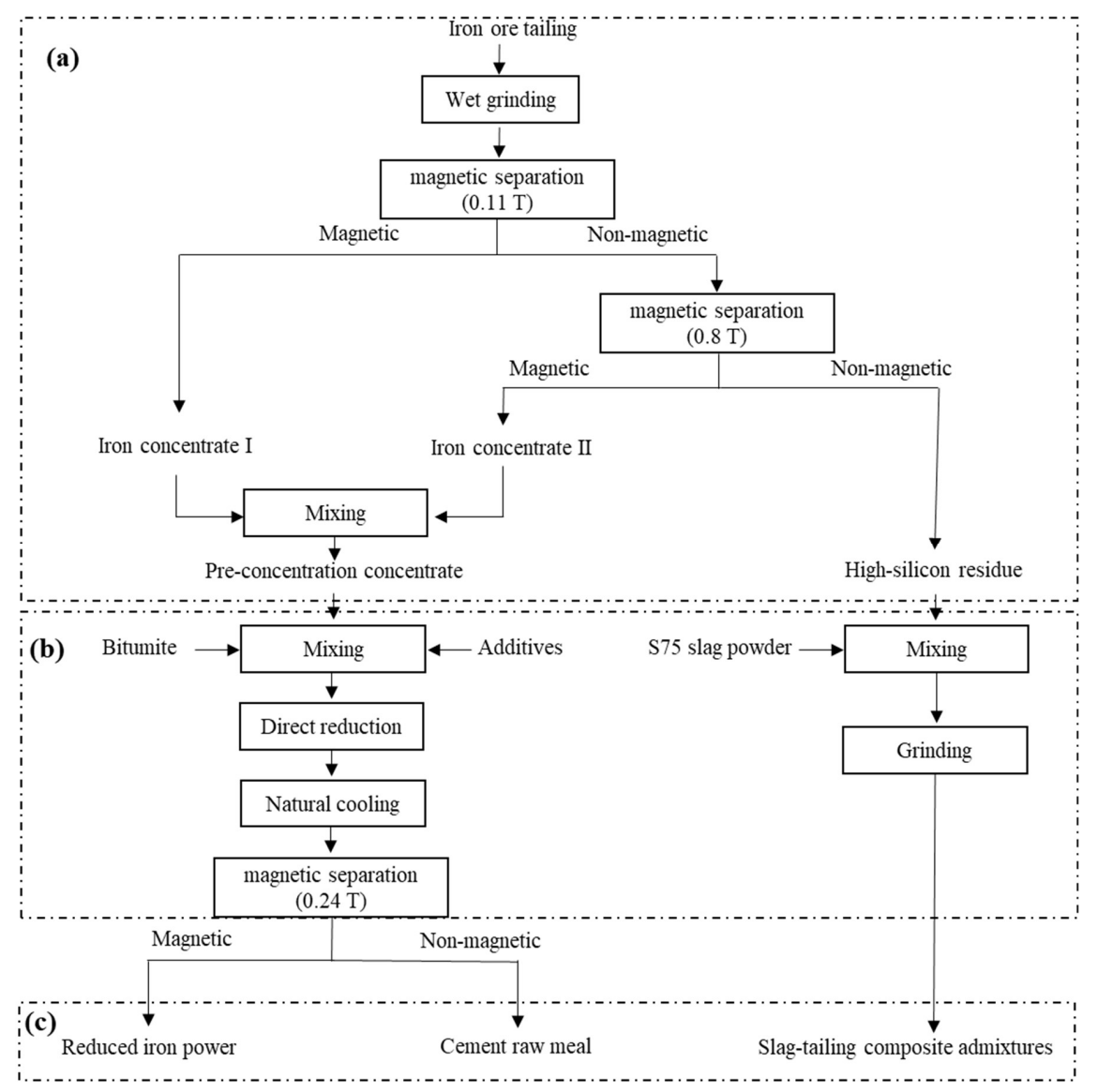

Figure 2. Experimental flowsheet: (a) The process of pre-concentration; (b) the process of iron recovery; (c) final products.

For pre-concentration, the IOTs were first milled to a size such that $50 \mathrm{wt} \%$ of particles were smaller than $38 \mu \mathrm{m}$. They were then separated in a low-intensity magnetic separator (model: RK/CXG; $\Phi=50 \mathrm{~mm}$; magnetic intensity: $0.11 \mathrm{~T}$, Hualian Mining Co., Ltd., Tianjin, China) followed by a high-intensity magnetic separator (model: RK/CSQ; $\Phi=50 \mathrm{~mm} \times 70 \mathrm{~mm}$; magnetic intensity: $0.8 \mathrm{~T}$, Bureau of geology and minerals 102, Xichang, China). The magnetic product was the pre-concentrated concentrate (PC), whereas the nonmagnetic product was the high-silicon residues that would be reused as concrete admixture.

For direct reduction-magnetic separation, a direct reduction was conducted in a muffle furnace (model: CD-1400, Oriental Electrical Instrument, Yuyao, China). Six sample groups were designed to investigate the effects of various parameters on iron recovery from IOTs, including roasting temperature, roasting time, the carbon-to-IOT ratio, as well as the ratio of the additives and the grinding fineness of the roasted product. The PC was mixed with bitumite and additives at different ratios. Afterwards, the mixtures were roasted at various temperatures and times, and the roasted products were air-cooled and wet-milled in a rod mill before being separated in a low-intensity magnetic separator with a magnetic field intensity of $0.24 \mathrm{~T}$. The iron grade of the reduced iron powder was chemically analyzed, and the recovery of iron was calculated based on the mass balance during the magnetic separation process. The nonmagnetic reducing slag (the chemical composition is presented in Table 4) in the roasted products was used as cement raw meal to directly burn a cement clinker, considering that the chemical composition was similar to that of cement raw materials. 
Table 4. Chemical composition of the reducing slag/wt \%.

\begin{tabular}{ccccccc}
\hline Components & $\mathrm{SiO}_{2}$ & $\mathrm{Fe}_{2} \mathrm{O}_{3}$ & $\mathrm{FeO}$ & $\mathrm{Al}_{2} \mathbf{O}_{3}$ & $\mathrm{CaO}$ & $\mathbf{M g O}$ \\
\hline Content & 59.57 & 1.36 & 1.93 & 3.10 & 24.81 & 2.65 \\
\hline Components & $\mathrm{Na}_{2} \mathbf{O}$ & $\mathrm{K}_{\mathbf{2}} \mathbf{O}$ & $\mathrm{MnO}$ & $\mathbf{S}$ & $\mathbf{P}$ & Loss \\
\hline Content & 0.97 & 0.52 & 0.10 & 0.10 & 0.02 & 4.27 \\
\hline
\end{tabular}

The process of preparing the concrete mineral admixture using high-silicon slag was as follows: S75 was mixed with high-silica residue in different proportions, and the mixtures were milled in the same mill for $30 \mathrm{~min}$, thus yielding slag-tailing composite admixtures for concrete with an ultrafine particle size, which was determined using a laser diffraction analyzer (model: LMS-30, Seishin Enterprise CO., Ltd., Osaka, Japan). Afterwards, the slag-tailing concrete composite admixtures ( $225 \mathrm{~g})$, Portland cement $(225 \mathrm{~g})$, and water $(225 \mathrm{~g}$ ) were mixed together and stirred slowly for $30 \mathrm{~s}$ in a mixer (model: NJ-160A, Jianyi Instrument and Machinery Co., Ltd., Wuxi, China), thus forming a cement paste. Then, sand $(1350 \mathrm{~g})$ was added to the mixer. The mixture was stirred rapidly for $30 \mathrm{~s}$ and poured into prismoidal molds $(40 \mathrm{~mm} \times 40 \mathrm{~mm} \times 160 \mathrm{~mm})$ on a vibration table running at a moderate vibration rate. All the samples were demolded after curing at $24 \mathrm{~h}$ under $90 \%$ humidity at $20 \pm 3{ }^{\circ} \mathrm{C}$ in a standard curing box (model: SHBY-40B, Luda Machinery Instrument, Shaoxing China). The samples were dipped in saturated lime water for curing under the same conditions. The compressive and flexural strengths of the cured specimens were tested after aging for 3,7 , and 28 days.

In this article, iron grade means the total iron (TFe) content, as detected by the chemical analysis (EDTA titration using the ethylenediamine tetra acetic acid as complexing agent to determine the chemical composition). The iron phases were determined using an atomic absorption spectrophotometer (model: AA-6800, Shimadzu, Kyoto, Japan) and titration. The mineral phases of the IOTs and roasted products were investigated using $\mathrm{X}$-ray diffraction (Ultima IV diffractometer with a copper target, $40 \mathrm{kV}, 40 \mathrm{~mA}$, scanning speed of $20^{\circ} \cdot \mathrm{min}^{-1}$, scanning angle of $10^{\circ}-100^{\circ}$, model: MXP21VAHF, MAC Science Co., Ltd., Osaka, Japan).

\section{Results and Discussion}

\subsection{Pre-Concentration}

The pre-concentration process was investigated using a previously described procedure [21,22]. The optimized conditions for pre-concentration were obtained from a previous work [22], and they were as follows: A particle size such that $50 \mathrm{wt} \%$ of the particles were smaller than $38 \mu \mathrm{m}$, a low magnetic field intensity of $0.11 \mathrm{~T}$, and a high magnetic induction of $0.8 \mathrm{~T}$. Under these conditions, the productivities of PC, the iron grade, and total iron recovery were $28.82 \mathrm{wt} \%, 36.58 \mathrm{wt} \%$, and 83.86 wt $\%$, respectively. The pre-concentration products are presented in Table 5. The chemical composition of the products is given in Table 6 .

Table 5. Pre-concentration products/wt \%. PC: Pre-concentrated concentrate.

\begin{tabular}{cccc}
\hline Products & Productivity Rate & Iron Grade & Iron Recovery Rate \\
\hline PC & 28.82 & 36.58 & 83.86 \\
High-silicon residue & 71.18 & 2.85 & 16.14 \\
IOTs & 100.00 & 12.57 & 100.00 \\
\hline
\end{tabular}

Table 6. Chemical composition of the pre-concentration products/wt $\%$.

\begin{tabular}{|c|c|c|c|c|c|c|c|c|c|c|c|c|}
\hline Products & $\mathrm{SiO}_{2}$ & $\mathrm{Fe}_{2} \mathrm{O}_{3}$ & $\mathrm{FeO}$ & $\mathrm{CaO}$ & $\mathrm{MgO}$ & $\mathrm{Al}_{2} \mathrm{O}_{3}$ & $\mathrm{Na}_{2} \mathrm{O}$ & $\mathrm{K}_{2} \mathrm{O}$ & $\mathrm{MnO}$ & $\mathrm{TiO}_{2}$ & $S$ & $\mathbf{P}$ \\
\hline PC* & 41.71 & 42.83 & 8.18 & 1.82 & 1.69 & 1.82 & 0.41 & 0.27 & 0.14 & 0.072 & 0.1 & 0.02 \\
\hline High-silicon residue $* *$ & 91.29 & 2.96 & 0.72 & 1.3 & 1.25 & 1.19 & 0.42 & 0.17 & 0.074 & 0.024 & 0.066 & 0.023 \\
\hline
\end{tabular}

* The PC was composed of iron concentrate I and Iron concentrate II; ${ }^{* *}$ high-silicon residue is the nonmagnetic component after the pre-concentration process. 


\subsection{Iron Recovery through Direct Reduction Followed by Magnetic Separation}

In order to improve iron recovery, sodium carbonate $\left(\mathrm{Na}_{2} \mathrm{CO}_{3}\right)$ and lime $(\mathrm{CaO})$ were used as additives in the reduction process. The effects of the bituminous content, roasting time, roasting temperature, sodium carbonate content, lime content, and grinding fineness of the roasted products on iron grade and iron recovery were studied.

\subsubsection{Effect of Bitumite Ratio on Iron Recovery}

When studying the influence of bituminous content on iron grade and iron recovery (based on previous studies [23-27]), the optimized conditions of sodium carbonate content, lime content, roasting temperature, roasting time, and fineness of roasted products were determined. The specific parameters used in the experiments were as follows: A 100:10:5 mixing ratio for PC/lime/sodium carbonate, respectively; a roasting temperature of $1150{ }^{\circ} \mathrm{C}$; and a roasting time of $60 \mathrm{~min}$. The grinding fineness of the roasted product at a $-74 \mu \mathrm{m}$ ratio was $65 \%$. The results are shown in Figure $3 \mathrm{a}$.
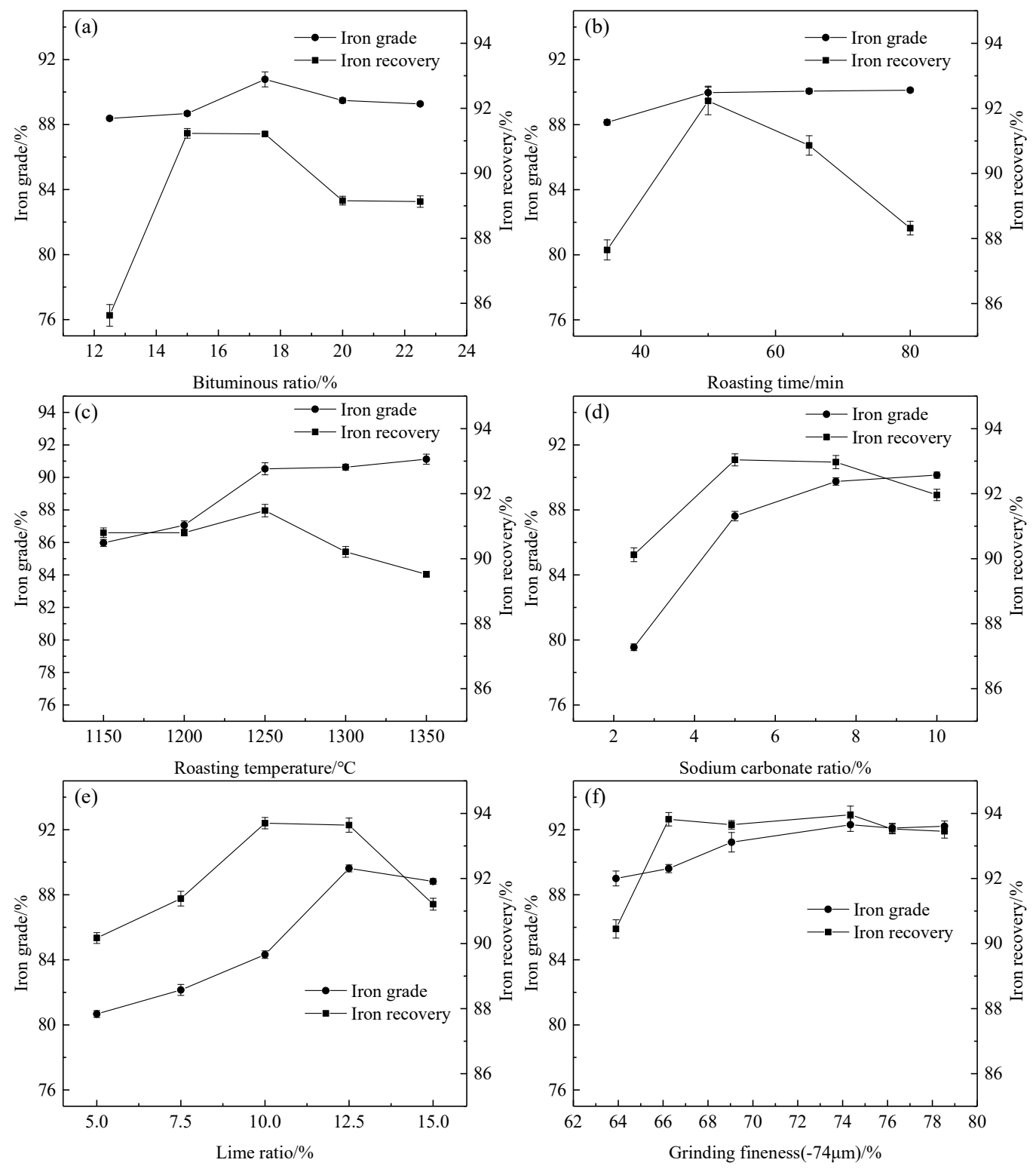

Figure 3. Effect of different influencing factors on iron recovery and iron grade: (a) Bituminous ratio; (b) roasting time; (c) roasting temperature; (d) sodium carbonate ratio; (e) lime ratio; (f) grinding fineness. 
Figure 3a shows that the iron grade and recovery rate increased rapidly as the bitumite ratio increased from $12.5 \mathrm{wt} \%$ to $17.5 \mathrm{wt} \%$, respectively. After reaching this value (17.5 wt \%), both quantities decreased. The iron recovery rate increased from $85.63 \mathrm{wt} \%$ to $9121 \mathrm{wt} \%$, indicating that increasing the bitumite dose significantly enhanced the iron recovery rate. However, when the bitumite was in excess, the reduced metallic iron could not overtake the porous coal and other gangue minerals. The increase in size of the metallic iron particles was hindered, which reduced iron recovery [15]. During this test, the optimal bitumite content was found to be $17.5 \mathrm{wt} \%$. Meanwhile, the increase in noncombustible substances in bituminous coal reduced the iron grade.

\subsubsection{Effect of Roasting Time on Iron Recovery}

The effect of roasting time on iron recovery was investigated under the following conditions: A 100:17.5:10:5 mixing ratio of $\mathrm{PC} /$ bitumite/lime/sodium carbonate, respectively; a roasting temperature of $1150{ }^{\circ} \mathrm{C}$; and a grinding fineness the same as that reported in Section 3.2.1. The corresponding experimental results are shown in Figure $3 b$.

As shown in Figure 3b, the iron recovery rates peaked after roasting for approximately $50 \mathrm{~min}$. As the roasting time increased from 35 to $50 \mathrm{~min}$, the iron recovery of the reduced iron powder increased from $87.65 \mathrm{wt} \%$ to $92.23 \mathrm{wt} \%$ before increasing slowly from 50 to $80 \mathrm{~min}$. Meanwhile, the iron grade maintained a stable trend. Consequently, the optimum roasting time was found to be $50 \mathrm{~min}$ for the following conditions: A 100:17.5:10:5 mixing ratio of PC/bitumite/lime/sodium carbonate, respectively; and a roasting temperature of $1150{ }^{\circ} \mathrm{C}$.

\subsubsection{Effect of Roasting Temperature on Iron Recovery}

The mixtures consisting of PC, bitumite, lime, and sodium carbonate in the mixing ratio of 100:17.5:10:5, respectively, were roasted for $50 \mathrm{~min}$ at various temperatures. The grinding fineness was the same as that reported in Section 3.2.1. Figure 3c shows that increasing the roasting temperature up to $1250{ }^{\circ} \mathrm{C}$ induced a rapid increase in the iron grade from $90.8 \mathrm{wt} \%$ to $91.48 \mathrm{wt} \%$. However, when the temperature exceeded $1250{ }^{\circ} \mathrm{C}$, the rate of improvement decreased dramatically. When the roasting temperature was too low, the metallic iron particles remained small and closely associated with the gangue minerals. Therefore, the gangue mineral particles were easily mixed with the metallic iron during the magnetic separation process. It is worth noticing that further increasing the roasting temperature improved the growth of the metallic iron particles [28]. When the roasting temperature exceeded $1350^{\circ} \mathrm{C}$, however, the metallic iron particles became coarser, and the minerals softened or melted, causing difficulty during grinding [29]. Consequently, a roasting temperature of $1250{ }^{\circ} \mathrm{C}$ was recommended as the optimum temperature.

\subsubsection{Effect of Sodium Carbonate Ratio on Iron Recovery}

In order to optimize the sodium carbonate dosage, various sodium carbonate ratios were studied, while the other process parameters were kept constant. The conditions were maintained as follows: A 100:17.5:10 mixing ratio of PC, bitumite, and lime, and roasting at $1250{ }^{\circ} \mathrm{C}$ for $50 \mathrm{~min}$. The grinding fineness was the same as that reported in Section 3.2.1. The corresponding results are presented in Figure $3 d$.

When the sodium carbonate ratio increased from $2.5 \mathrm{wt} \%$ to $7.5 \mathrm{wt} \%$, the iron grade of the reduced iron powder increased from $81.55 \mathrm{wt} \%$ to $91.75 \mathrm{wt} \%$, respectively, whereas the recovery of iron increased from $90.12 \mathrm{wt} \%$ to $92.97 \mathrm{wt} \%$, respectively. When the sodium carbonate ratio exceeded $7.5 \mathrm{wt} \%$, no obvious improvements were observed in the iron recovery. When sodium carbonate was present, it reacted with $\mathrm{SiO}_{2}$ in the gangue minerals to form low-melting phases, such as $\mathrm{Na}_{2} \mathrm{O} \cdot \mathrm{SiO}_{2}$, $2 \mathrm{Na}_{2} \mathrm{O} \cdot \mathrm{SiO}_{2}$, and $\mathrm{Na}_{2} \mathrm{O} \cdot 2 \mathrm{SiO}_{2}$ (melting point of $1088^{\circ} \mathrm{C}$ ), during the direct reduction. Furthermore, the liquid phase was composed of $\mathrm{Na}_{2} \mathrm{O} \cdot \mathrm{SiO}_{2}, 2 \mathrm{Na}_{2} \mathrm{O} \cdot \mathrm{SiO}_{2}$, and $\mathrm{Na}_{2} \mathrm{O} \cdot 2 \mathrm{SiO}_{2}$, which were formed locally [30]. When a liquid phase is present in roasted products, the diffusion coefficient increases, thus accelerating the diffusion and migration of iron in some cases and causing the metallic iron particles to 
gather and grow rapidly $[28,31,32]$. Based upon these results, the optimum sodium carbonate content was found to be $7.5 \mathrm{wt} \%$.

\subsubsection{Effect of Lime Ratio on Iron Recovery}

The effect of lime content on iron recovery was also studied. The samples consisted of PC, bitumite, and sodium carbonate in a ratio of $100: 17.5: 7.5$, respectively, and they were roasted at $1250{ }^{\circ} \mathrm{C}$ for 50 $\mathrm{min}$. The grinding fineness was the same as that reported in Section 3.2.1. The corresponding results are shown in Figure 3e. It can clearly be seen that increasing the ratio of lime from $5 \mathrm{wt} \%$ to $12.5 \mathrm{wt} \%$ increased the iron grade from $80.67 \mathrm{wt} \%$ to $89.62 \mathrm{wt} \%$, whereas the corresponding iron recovery increased from $90.17 \mathrm{wt} \%$ to $93.64 \mathrm{wt} \%$. When the lime addition ratio exceeded $12.5 \mathrm{wt} \%$, both the iron grade and recovery rate decreased. Based upon the results, the optimum sodium carbonate content was chosen to be $12.5 \mathrm{wt} \%$.

Lime is a common and low-cost reaction additive that is used to improve the reduction of iron ore. Because PC contains numerous $\mathrm{SiO}_{2}$ groups, the poor reactivity of fayalite, which forms readily during the reaction between $\mathrm{FeO}$ and $\mathrm{SiO}_{2}$, is expressed using Equation (1):

$$
\mathrm{FeO}+\mathrm{SiO}_{2}=\mathrm{FeO} \cdot \mathrm{SiO}_{2} .
$$

When the lime is added, it reacts with $\mathrm{SiO}_{2}$ instead of $\mathrm{FeO}$ in the gangues to form calcium silicate $\left(\mathrm{CaO} \cdot \mathrm{SiO}_{2}\right)$ during reduction roasting, and meanwhile bituminous coal participates in the reaction as a reducing agent. This reaction can be expressed using Equation (2):

$$
\mathrm{FeO} \cdot \mathrm{SiO}_{2}+\mathrm{CaO}+\mathrm{C}=\mathrm{Fe}+\mathrm{CaO} \cdot \mathrm{SiO}_{2}+\mathrm{CO} \uparrow \text {. }
$$

Consequently, more $\mathrm{FeO}$ can be reduced to metallic iron, enhancing the direct reduction process of iron oxide.

\subsubsection{Effect of the Grinding Fineness of the Roasted Product on Iron Recovery}

Complete mineral liberation is essential when magnetically separating metallic iron particles [15]. Consequently, the roasted product must be ground before magnetic separation. The effect of the grinding fineness of the roasted product was also studied under the following conditions: A roasting temperature of $1250{ }^{\circ} \mathrm{C}$, a roasting time of $50 \mathrm{~min}$, and a mixing ratio of 100:17.5:12.5:7.5 of PC, bitumite, lime, and sodium carbonate, respectively. The effect of the grinding fineness of the roasted product on iron recovery is shown in Figure 3f. The relationship between the grinding fineness and grinding time of the roasted product is presented in Table 7.

Table 7. Relationship between grinding fineness and grinding time of the roasted product/wt \%.

\begin{tabular}{ccccccc}
\hline Grinding Time/min & $\mathbf{1 0}$ & $\mathbf{1 5}$ & $\mathbf{2 0}$ & $\mathbf{2 5}$ & $\mathbf{3 0}$ & $\mathbf{3 5}$ \\
\hline Grinding fineness $(-74 \mu \mathrm{m}) / \mathrm{wt} \%$ & 63.9 & 66.25 & 69.05 & 74.35 & 76.21 & 78.54 \\
\hline
\end{tabular}

Figure $3 \mathrm{f}$ shows that as the grinding time was prolonged and the grinding fineness increased, the iron grade of the reduced iron powder and the iron recovery initially increased and then stabilized. When $74.35 \mathrm{wt} \%$ of the particles were smaller than $74 \mu \mathrm{m}$, the metallic iron particles were almost completely liberated, generating an iron grade of $92.30 \mathrm{wt} \%$ and an iron recovery of $93.96 \mathrm{wt} \%$. Generally, the finer the grinding fineness, the more difficult the recovery of magnetic fraction is. When the grinding fineness was $-74 \mu \mathrm{m}$, the iron recovery was not improved relative to $66 \mu \mathrm{m}$, though the iron grade improved. Due to this reason, $-74 \mu \mathrm{m}$ was chosen as the optimum grinding fineness. 


\subsubsection{XRD Analysis of the Roasted Product}

The roasted products were analyzed using XRD to explain the experimental results discussed above. The XRD pattern of the roasted product is shown in Figure 4.

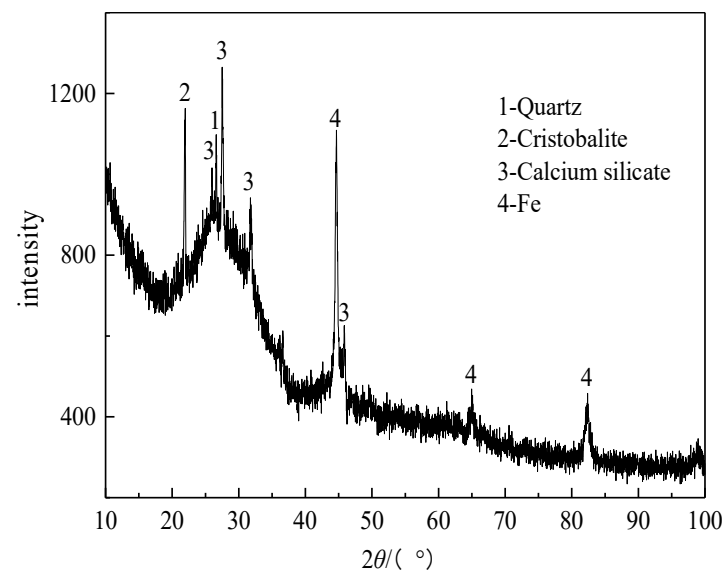

Figure 4. XRD pattern of the roasted product.

Figure 4 shows that the peaks for metallic iron appeared without evidence of any other iron compounds in the roasted product, indicating that the iron-bearing minerals were almost completely reduced to metallic iron. The impurities included calcium silicate, cristobalite, and some residual quartz, as well as amorphous forms of the roasted product. Under high temperature conditions, a liquid phase formed in large amounts during the reduction. This liquid phase accelerated the growth of metallic iron particles.

This study did not investigate the combined effects of sodium carbonate, lime, and other factors on iron recovery. The optimum parameters determined by the above single factor test were found to be a roasting temperature of $1250{ }^{\circ} \mathrm{C}$; a roasting time of $50 \mathrm{~min}$; a mixing ratio of 100:17.5:12.5:7.5 of PC, bitumite, lime, and sodium carbonate, respectively; and the proportion of $-74 \mu \mathrm{m}$ being more than $74.35 \mathrm{wt} \%$. Under such conditions, the iron grade and iron recovery rate were found to be $92.30 \mathrm{wt} \%$ and $93.96 \mathrm{wt} \%$, respectively. Specifically, $78.79 \mathrm{wt} \%$ of the iron could be recovered from Qidashan IOTs through pre-concentration followed by direct reduction and magnetic separation. The XRD pattern showed that the main phase in the roasted product was metallic iron.

\subsection{Preparation of Slag-Tailing Concrete Composite Admixtures Using the High-Silica Residues}

Since the main component of high-silica residues is $\mathrm{SiO}_{2}$, which has no mineral activity, it is necessary to prepare concrete mineral admixtures using mechanical excitation. Therefore, a grinding test was carried out. The method for determining the optimized grinding time and method was based on the approach of Huang [33] and was as follows: First, S75 and high-silica residue were mixed according to the ratios given in Table 8, and the mixture was ground for $30 \mathrm{~min}$. Then, a cement mortar test block was prepared using ground composite admixtures of cement, ISO sand, and water. The mixing proportions of the cement mortar are presented in Table 9. The specific surface area of each group mixture, fluidity, and the compressive strength of each group mortar were investigated. Group C-0 was made of pure cement and ISO sand as a blank group for a calculation of the activity index of the composite admixtures. 
Table 8. Composite admixture proportions/wt \%.

\begin{tabular}{ccc}
\hline Number & S 75 & Tailing \\
\hline S-0 & 100 & 0 \\
S-10 & 90 & 10 \\
S-20 & 80 & 20 \\
S-30 & 70 & 30 \\
S-40 & 60 & 40 \\
S-50 & 50 & 50 \\
\hline
\end{tabular}

Table 9. Mixing proportion of cement mortar/g.

\begin{tabular}{ccccc}
\hline Number & Cement & Composite Admixture & ISO Sand & Water \\
\hline C-0 & 450 & 0 & 1350 & 225 \\
CS-0 CS50* & 225 & 225 & & \\
\hline
\end{tabular}

CS-0 CS50* represents cement mortar when the composite admixtures were numbered S-0, S-10, S-20, S-30, S- 40 , or S-50.

\subsubsection{Chemical Composition and Mineral Phases of the High-Silica Residues}

According to the data shown in Table 6, the $\mathrm{SiO}_{2}$ content of the high-silica residues was $91.29 \mathrm{wt} \%$. The XRD pattern of the high-silica residues is shown in Figure 5. The main crystalline phase was quartz, with small amounts of hematite and hornblende.

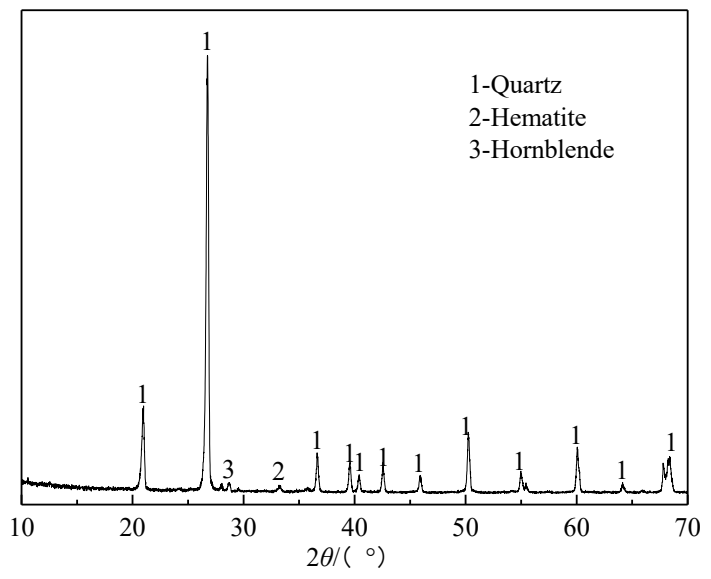

Figure 5. XRD pattern of the high-silica residues.

3.3.2. Specific Surface Area of the Slag-Tailing Composite Admixture and the Working Performance of the Mortar

Figure 6a shows the specific surface area of each group slag-tailing composite admixture after grinding for $30 \mathrm{~min}$. The specific surface area of each group from S-0 to S-50 increased sequentially, indicating that the grindability of the mixture improved with an increase in the content of high-silica residue. Meanwhile, the energy consumption of the grinding could be reduced in industrial production.

The fluidity and fluidity ratio of each group mortar are shown in Figure $6 \mathrm{~b}$. The results show that both the fluidity and fluidity ratio increased with an increase in the content of high-silica residue. This was because the content of the fine particles increased: Due to this, the gap between the mortars could be filled, and the amount of interstitial water was reduced. The calculation of the fluidity ratio revealed that the fluidity values of each group were comparable to the reference group (Group C-0). Within a certain range, the greater the fluidity ratio, the better the performance of the mortar was. However, the compressive strength and fluidity of the mortar, which are the main properties of mineral admixtures, should be considered simultaneously for determining the optimum proportion. 

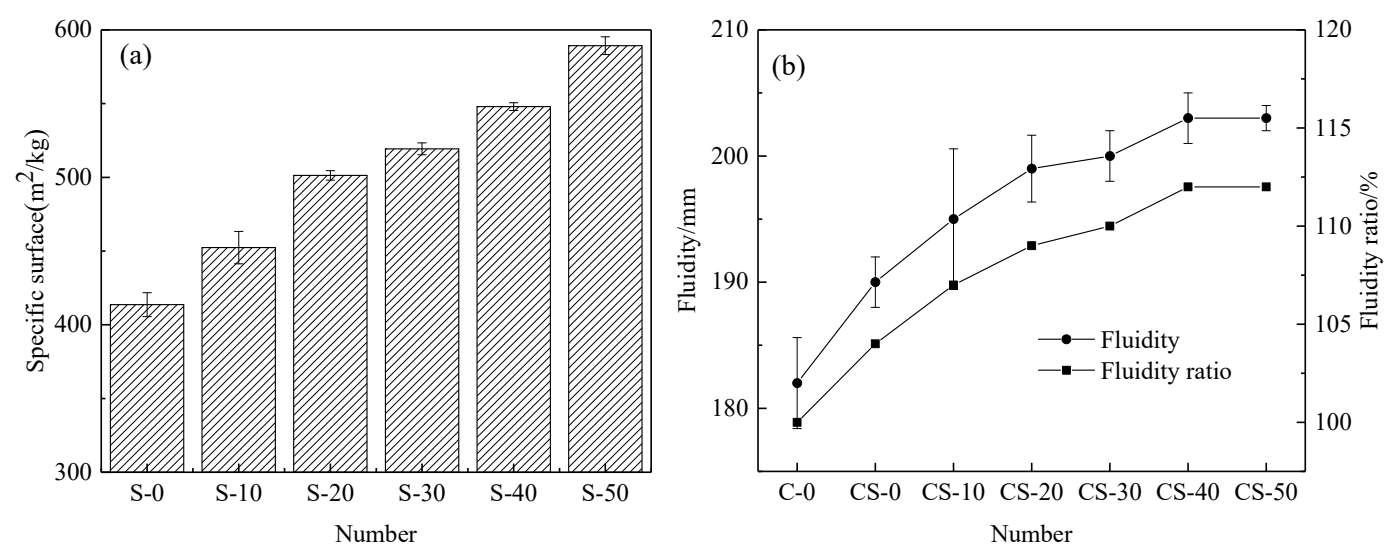

Figure 6. Specific surface area and workability of the slag-tailing: (a) Specific surface area when ground for $30 \mathrm{~min}$; (b) fluidity and fluidity ratio of mortars.

\subsubsection{Compressive Strength and Activity Index of Mortar}

The activity index of concrete mineral admixtures should be considered when high-silica residue is used to prepare slag-tailing composite admixtures. Figure 7 shows the compressive strength of mortars and the activity index of the slag-tailing admixture.
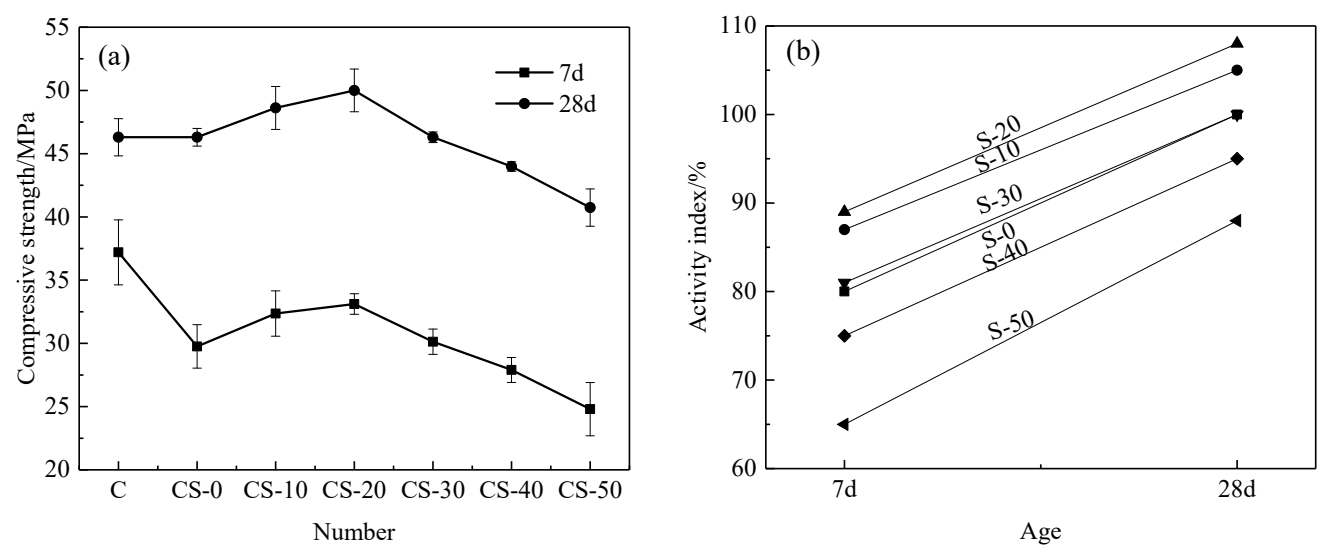

Figure 7. Compressive strength of mortars and activity index of slag-tailing admixture: (a) Compressive strength of mortars; (b) activity index of slag-tailing admixture.

From Figure 7a, it can be seen that with an increase in the content of high-silica residue, the compressive strength of each group of mortar first increased and then decreased. This was due to the reason that high-silica residues are inert materials comparable to blast furnace slag, whereas the strength of mortar can be increased by physical filling with a low content of high-silica residues. The compressive strength of 7 days and 28 days in the CS-20 group was the highest, reaching values of 33.11 MPa and $50 \mathrm{MPa}$, respectively.

The activity index is one of the main indicators for evaluating the quality of mineral admixtures, and their calculation method was based upon the compressive strength of each group compared to the blank group. Figure $7 \mathrm{~b}$ shows the activity index of different ages of each group. It is clear that the activity index of mineral materials did not decrease when the amount of blast furnace slag replaced by tailings did not exceed $30 \%$. Furthermore, the 7-day and 28-day activity indices of the S-20 group reached values of 89 and 108, respectively, which exceeded the activity index of the S-0 group without high-silica residues. The high activity of the S-20 group was primarily attributed to high-silica residue, which contained large quantities of ultrafine particles with diameters of less than $5 \mu \mathrm{m}$ (the particle size distribution curve for the slag-tailing admixtures of S-20 is shown in Figure 8). These particles not only served as filling materials, thus increasing the compactness of the matrix, 
but also as nucleation catalysts, which accelerated the cement hydration process [34,35]. When only the quality of the slag-tailing admixture was considered, the S-20 group came out as being the best among all. However, the S-30 group may be more suitable if the maximum use of high-silica residue is considered.

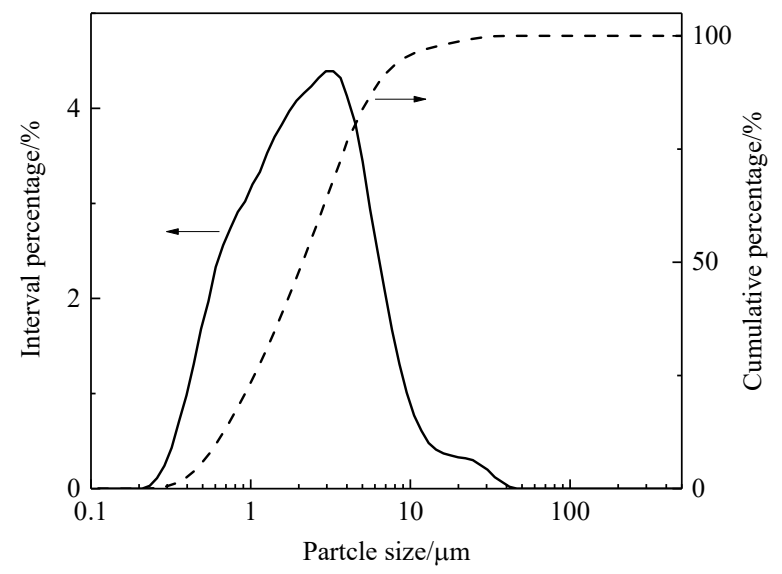

Figure 8. Particle size distribution curve for the slag-tailing admixtures of CS-20.

\section{Conclusions}

This paper demonstrated an innovative technical method called "pre-concentration followed by direct reduction and magnetic separation technology", which was developed to completely utilize IOTs. This method recovers a large amount of iron while solving the problem of secondary storage of reducing slag and high-silica residues. Based on the obtained results, the following conclusions can be drawn:

1. Primary grinding was followed by low-intensity magnetic separation and subsequent high-intensity magnetic separation processes to concentrate the iron in IOTs. The PC was characterized by an iron grade of $36.58 \mathrm{wt} \%$ and a total iron recovery of $83.86 \mathrm{wt} \%$ when $50 \mathrm{wt} \%$ of the particles were smaller than $0.038 \mathrm{~mm}$, and the magnetic separation was conducted with a low magnetic field intensity of $0.11 \mathrm{~T}$ and a high magnetic induction of $0.8 \mathrm{~T}$. Furthermore, high-silicon residues containing $91.29 \mathrm{wt} \% \mathrm{SiO}_{2}$ were obtained;

2. The bitumite ratio, roasting temperature, roasting time, lime ratio, sodium carbonate ratio, and particle size of the roasted product were the six major factors that influenced iron recovery. Optimal reduction conditions were obtained as follows: A roasting temperature of $1250{ }^{\circ} \mathrm{C}$, a roasting time of $50 \mathrm{~min}$, and a mixing ratio of 17.5:7.5:12.5:100 ratio of bitumite/sodium carbonate/lime/PC, respectively. Under these conditions, the iron grade of the reduced iron powder was found to be $92.30 \mathrm{wt} \%$, and the iron recovery rate was $93.96 \mathrm{wt} \%$. Relative to the original IOTs, the iron recovery was $78.79 \mathrm{wt} \%$;

3. When the amount of high-silica residues replacing blast furnace slag was $20 \%$, the strength of the cement mortar was $33.11 \mathrm{MPa}$ and $50 \mathrm{MPa}$ at 7 days and 28 days, respectively, whereas the corresponding activity index was 89 and 108, respectively, Furthermore, the fluidity rate of the mortar was approximately 109 . When the content of high-silica residues replacing blast furnace slag was not more than $30 \%$, the quality of slag-tailing concrete composite admixtures was not reduced;

4. Iron was recovered from IOTs through pre-concentration followed by direct reduction and magnetic separation processes. Moreover, the high-silica residues from the pre-concentration process were reused in slag-tailing concrete composite admixtures. Combining these recycling processes can ensure complete utilization of IOTs; 
5. Incorporating an extra pre-concentration step before the direct reduction circumvented the high costs of recovering small amounts of iron through direct reduction. Consequently, this innovative technology can be extended to other IOTs with low iron content, exhibiting high potential for many other applications.

Author Contributions: C.T. performed the experiment, wrote the manuscript, and analyzed the data with the help of D.F.; K.L. revised the manuscript; W.N. designed the experiment.

Funding: This research was funded by the Ministry of Science and Technology International Science and Technology Cooperation Program, grant number 2016YFE0130700.

Acknowledgments: The authors would also like to thank the Analytical and Testing Centre of the University of Science and Technology Beijing, China University of Geoscience, and the Xi'an Tianzhou Mining Science and Technology Development Co., Ltd., of China, which supplied the facilities necessary for data collection.

Conflicts of Interest: The authors declare no conflicts of interest.

\section{References}

1. Jiang, J.H.; Ye, G.H.; Hu, S.M. The technology status and research progress of iron tailings re-beneficiation. Min. Metall. 2018, 27, 1-4.

2. Zhizhen, L.; Xinjian, G.; Resource, S.O. Current Situations of Tailings Utilization and Sustainable Development of Mines. Miner. Eng. Res. 2018, 116, 37-41.

3. Chen, H.A.; Shen, W.G.; Shan, L.; Xiong, C.B.; Su, Y.Q.; Liu, B.; Rao, J.L. Situation of discharge and comprehensive utilization of iron tailings domestic and abroad. Concrete 2012, 2, 88-91.

4. Jiabin, C.; Wenlong, J.; Lianghui, Y. Survey and Evaluation of the Iron Tailings Resources in China. Min. Res. Dev. 2010, 3, 60-62.

5. Ajaka, E.O. Recovering fine iron minerals from Itakpe iron ore process tailing. ARPN J. Eng. Appl. Sci. 2009, $4,17-28$.

6. Rao, K.H.; Narasimhan, K.S. Selective flocculation applied to Barsuan iron ore tailings. Int. J. Miner. Process. $1985,14,67-75$.

7. Han, J.; Zhu, S.; Xun, Z.; Zhao, G. Experimental Research on Mineral Separation of a Magnetic-flotation Tailings Mixture. Min. Res. Dev. 2012, 2, 37-43.

8. Sakthivel, R.; Vasumathi, N.; Sahu, D.; Mishra, B.K. Synthesis of magnetite powder from iron ore tailings. Powder Technol. 2010, 201, 187-190. [CrossRef]

9. Das, S.K.; Kumar, S.; Ramachandrarao, P. Exploitation of iron ore tailing for the development of ceramic tiles. Waste Manag. 2000, 20, 725-729. [CrossRef]

10. Das, S.K.; Ghosh, J.; Mandal, A.K.; Singh, N.; Gupta, S. Iron ore tailing: A waste material used in ceramic tile compositions as alternative source of raw materials. Trans. Indian Ceram. Soc. 2012, 71, 21-24. [CrossRef]

11. Huang, X.; Ranade, R.; Li, V.C. Feasibility study of developing green ECC using iron ore tailings powder as cement replacement. J. Mater. Civ. Eng. 2013, 25, 923-931. [CrossRef]

12. Adedayo, S.M.; Onitiri, M.A. Mechanical properties of iron ore tailings filled-polypropylene composites. J. Miner. Mater. Charact. Eng. 2012, 11, 671. [CrossRef]

13. Adedayo, S.M.; Onitiri, M.A. Tensile properties of iron ore tailings filled epoxy composites. West. Indian J. Eng. 2012, 35, 51-59.

14. Chun, T.J.; Zhu, D.Q.; Pan, J.; He, Z. Preparation of metallic iron powder from red mud by sodium salt roasting and magnetic separation. Can. Metall. Q. 2014, 53, 183-189. [CrossRef]

15. Yang, H.; Jing, L.; Zhang, B. Recovery of iron from vanadium tailings with coal-based direct reduction followed by magnetic separation. J. Hazard. Mater. 2011, 185, 1405-1411. [CrossRef]

16. Zhang, G.F.; Yang, Q.R.; Yang, Y.D.; Wu, P.; McLean, A. Recovery of iron from waste slag of pyrite processing using reduction roasting magnetic separation method. Can. Metall. Q. 2013, 52, 153-159. [CrossRef]

17. Maweja, K.; Mukongo, T.; Mutombo, I. Cleaning of a copper matte smelting slag from a water-jacket furnace by direct reduction of heavy metals. J. Hazard. Mater. 2009, 164, 856-862. [CrossRef]

18. Zhang, Y.; Li, H.; Yu, X. Recovery of iron from cyanide tailings with reduction roasting-Water leaching followed by magnetic separation. Adv. Mater. Res. 2012, 396, 486-489. [CrossRef] 
19. Li, C.; Sun, H.; Bai, J.; Li, L. Innovative methodology for comprehensive utilization of iron ore tailings: Part 1. The recovery of iron from iron ore tailings using magnetic separation after magnetizing roasting. J. Hazard. Mater. 2010, 174, 71-77. [CrossRef]

20. Ni, W.; Fu, C.H.; Fan, D.C.; Li, J.; Qiu, X.J.; Li, Y. A Method of Extracting Iron Ore Tailings by Deep Reduction after Using Strong Magnetism to Pre-concentrate the Tailings. Chinese Patent No. 201210362689.3, 11 September 2013.

21. Li, J.; Ni, W.; Fan, D.C.; Li, Y.; Fu, C.H. Process Mineralogy Research on Iron Tailings from Qidashan. Metal Mine 2014, 1, 158-162.

22. Fan, D. Research on Pre-Concentration and Deep Reduction of Qidashan Iron Ore Tailings and the Comprehensive Utilization of Tailings; University of Science and Technology Beijing: Beijing, China, 2018.

23. Zhu, D.Q.; Chun, T.J.; Pan, J.; He, Z. Recovery of Iron from High-Iron Red Mud by Reduction Roasting with Adding Sodium Salt. J. Iron Steel Res. Int. 2012, 19, 1-5. [CrossRef]

24. Yu, W.; Sun, Y.; Liu, Z.; Kou, J.; Xu, C. Effects of particle sizes of iron ore and coal on the strength and reduction of high phosphorus oolitic hematite-coal composite briquettes. ISIJ Int. 2014, 54, 56-62. [CrossRef]

25. Yu, W.; Sun, T.; Kou, J.; Wei, Y.; Xu, C.; Liu, Z. The function of $\mathrm{Ca}(\mathrm{OH})_{2}$ and $\mathrm{Na}_{2} \mathrm{CO}_{3}$ as additive on the reduction of high-phosphorus oolitic hematite-coal mixed pellets. ISIJ Int. 2013, 53, 427-433. [CrossRef]

26. Zhu, D.; Chun, T.; Pan, J.; Lu, L.; He, Z. Upgrading and dephosphorization of Western Australian iron ore using reduction roasting by adding sodium carbonate. Int. J. Miner. Metall. Mater. 2013, 20, 505-513. [CrossRef]

27. Fan, D.; Ni, W.; Wang, J.; Wang, K. Effects of $\mathrm{CaO}$ and $\mathrm{Na}_{2} \mathrm{CO}_{3}$ on the reduction of high silicon iron ores. J. Wuhan Univ. Technol. -Mater. Sci. Ed. 2017, 32, 508-516. [CrossRef]

28. Weissberger, S.; Zimmels, Y.; Lin, I.J. Mechanism of growth of metallic phase in direct reduction of iron bearing oolites. Metall. Trans. B 1986, 17, 433-442. [CrossRef]

29. Ni, W.; Yan, J.; Cheng, Y. Beneficiation of unwieldy oolitic hematite by deep reduction and magnetic separation process. Chin. J. Eng. 2010, 32, 287-291.

30. Hao, Z.; Wu, S.; Wang, Y.; Luo, G.; Wu, H.; Duan, X. Acting mechanism of F, K, and Na in the solid phase sintering reaction of the Baiyunebo iron ore. Int. J. Miner. Metall. Mater. 2010, 17, 137-142. [CrossRef]

31. Nadiv, S.; WeissbergerI, S.; Lin, J.; Zimmels, Y. Diffusion mechanisms and reactions during reduction of oolitic iron-oxide mineral. J. Mater. Sci. 1988, 23, 1050-1055. [CrossRef]

32. Li, G.; Zhang, S.; Rao, M.; Zhang, Y.; Jiang, T. Effects of sodium salts on reduction roasting and Fe-P separation of high-phosphorus oolitic hematite ore. Int. J. Miner. Process. 2013, 124, 26-34. [CrossRef]

33. Huang, X.Y.; Ni, W.; Zhu, L.-P.; Wang, Z.-J. Grinding characteristic of Qidashan iron tailings. J. Univ. Sci. Technol. Beijing 2010, 32, 1253-1257.

34. Kronlöf, A. Effect of very fine aggregate on concrete strength. Mater. Struct. 1994, 27, 15-25. [CrossRef]

35. Lawrence, P.; Cyr, M.; Ringot, E. Mineral admixtures in mortars: Effect of inert materials on short-term hydration. Cem. Concr. Res. 2003, 33, 1939-1947. [CrossRef]

(C) 2019 by the authors. Licensee MDPI, Basel, Switzerland. This article is an open access article distributed under the terms and conditions of the Creative Commons Attribution (CC BY) license (http://creativecommons.org/licenses/by/4.0/). 